\section{Colour Reaction for Certain Mercaptoimidazoles}

IN a recent communication ${ }^{1}$, I described a new colour reaction for the antithyroid drugs, 2 -thiouracil and 4-methyl-2-thiouracil. This is based upon the yellow colour which is given when small concentrations of the drugs are treated with $2: 6$-dichloroquinone-chloroimide at $p \mathrm{H} 8 \cdot 0$. Although some free amino-acids, purines and other urinary solutes give coloured products in the reaction, these latter are insoluble in chloroform, whereas within certain con. centration limits the coloured products of the reaction with the drugs are readily extractable from the aqueous phase by this solvent. By this means the colour reaction has been made specific, and has been applied to the colorimetric determination of methylthiouracil in urine.

Recently, Stanley and Astwood ${ }^{2}$ and others have deseribed the clinical use of antithyroid compounds of the mercaptoimidazole type, which have been shown to have a much higher in vivo activity than the thiouracils. In view of this we have been interested in the behaviour of certain mercaptoimidazoles in the above colour reaction, as a potential method for their determination.

Compounds of this type examined were 2-mercaptoimidazole, 4-methyl-2-mercaptoimidazole, and 4amino-methyl-2-mercaptoimidazole (hydrochloride). These were dissolved in distilled water, and the $p H$ of their solutions brought to 8.0 by the cautious addition of decinormal sodium hydroxide. After suitable dilution, aliquots of the solutions were taken and mixed with $2 \mathrm{ml}$. of a borate buffer, $p \mathrm{H} 8 \cdot 0$, and $0.1 \mathrm{ml}$. of a 0.4 per cent solution of $2: 6$-dichloroquinone-chloroimide in aldehyde-free absolute ethanol. Colour formation in each case was very rapid. Once the solutions had stood for $10 \mathrm{~min}$. at room temperature, the solubility of the coloured complexes in chloroform was determined by shaking the solutions with $5 \mathrm{ml}$. of this solvent (see table). The amount of compound tested in each case was $0.5 \mathrm{mgm}$.

\begin{tabular}{|c|c|c|}
\hline Compound & Colour reaction & $\begin{array}{c}\text { Solubility in } \\
\text { chloroform }\end{array}$ \\
\hline $\begin{array}{l}\text { 2-Mercaptoimidazole } \\
\text { 4-Methyl-2-mercaptoimidazole } \\
\text { 4-Amino-methyl-2-mercaptoimid- } \\
\text { azole }\end{array}$ & $\begin{array}{l}\text { Rapid; deep red } \\
\text { Rapid; deep red } \\
\text { Rapid ; orange }\end{array}$ & $\begin{array}{l}\text { Soluble } \\
\text { Soluble }\end{array}$ \\
\hline
\end{tabular}

The sensitivity of the colour reaction for each of the compounds tested was in the region of $10 \mu \mathrm{gm}$. Of the three compounds tested, the 2-mercaptoimidazole and the 4-methyl-2-mercaptoimidazole gave the best results as based upon the stability of their coloured products. The 4-amino-methyl-2mercaptoimidazole gave an orange-coloured product which tended to decompose. Imidazole-4-5-dicarboxylic acid gave no colour in the reaction.

In spite of the preliminary nature of this work, it would appear that other compounds of the mercaptoimidazole type would behave analogously in the reaction, since the introduction of a methyl group at position 4 in the 2-mercaptoimidazole made no appreciable difference in the colour reaction. Since chloroform exhibits a selective solvent action in this instance, as it does in the case of the thiouracil reaction, it is believed that the colour reaction for the mercaptoimidazoles could be made the basis of a useful method for their determination. Whether this would be applicable to the determination of the compounds in urine is, of course, based upon whether these are excreted as such. A more detailed de. scription of this work will be published elsewhere.

I am indebted to Dr. W. R. Trotter, of University College Hospital Medical School, London, for samples of the mercaptoimidazoles used; these were prepared by Dr. A. Lawson, of the Royal Free Hospital School of Medicine, to whom also thanks are due.

Ronald A. McAliLISTer

Biochemical Laboratory,

Royal Samaritan Hospital, Glasgow. Jan. 11.

${ }^{1}$ McAllister, R. A., Nature, 168, 789 (1950).

2 Stanley, M. M., and Astwood, F. B., Endocrin., 44, 588 (1949).

\section{Purely Aliphatic Azoxy Compounds with a Methyl Group attached to the Nitrogen Atom}

Aliphatic azoxy compounds were first synthesized by one of us in $1931^{1,2}$, but all contained only tertiary alkyl groups attached to nitrogen.

In view of the work being carried out at Cambridge by Lythgoe and collaborators ${ }^{3}$ on the natural product, macrozamin, which apparently contains an azoxy group with a methyl group directly attached, it seems worth while to make available our results on the synthesis of an azoxy compound containing such a group.

We have synthesized methyl-2-azoxy-2,5-dimethylhexane,

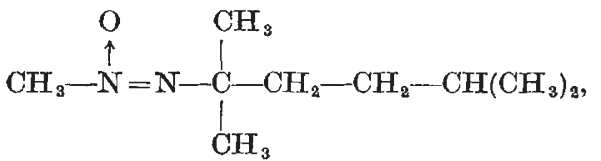

by the condensation of $\mathrm{N}$-methylhydroxylamine with 2-nitroso-2,5-dimethylhexane by a method similar to that reported by one of us.

A suspension was made of $8.0 \mathrm{gm} .(0 \cdot 145 \mathrm{~mole})$ of powdered potassium hydroxide in $100 \mathrm{ml}$. of dry ether, and to this was added with stirring over a 20 -min. period $9 \cdot 3 \mathrm{gm}$. $(0.112 \mathrm{~mole})$ of N-methyl. hydroxylamine hydrochloride. The ether was removed with an aspirator at $60 \mathrm{~mm}$. pressure to leave a slightly yellow, curdy solid. To this was added at once $16 \cdot 0 \mathrm{gm}$. $(0.112 \mathrm{~mole})$ of bis-2-nitroso-2,5-dimethylhexane. The mixture was heated to the melting point of the nitroso compound, whereupon a vigorous reaction ensued which required rapid cooling. When the reaction had subsided, the mixture was heated to $85^{\circ}$ for $1 \mathrm{hr}$, and then to $110^{\circ}$ for an additional $2 \mathrm{hr}$. After cooling, $40 \mathrm{ml}$. of water and $50 \mathrm{ml}$. of ether were added and the layers separated. The aqueous layer was extracted again with $25 \mathrm{ml}$. of ether. The combined ether extract was dried over sodium sulphate. After distilling the ether, the residue was distilled at $35 \mathrm{~mm}$. pressure and gave the fractions shown in the accompanying table.

\begin{tabular}{|c|c|c|c|}
\hline Fraction & $\begin{array}{l}\text { Vapour temp. } \\
\left({ }^{\circ} \mathrm{C} .\right)\end{array}$ & $\begin{array}{l}\text { Weight of } \\
\text { fraction }\end{array}$ & $\begin{array}{l}\text { Colour of } \\
\text { distillate }\end{array}$ \\
\hline $\begin{array}{l}1 \\
2 \\
3\end{array}$ & $\begin{array}{r}32^{\circ}-91^{\circ} \\
91^{\circ}-103^{\circ} \\
103^{\circ}-105^{\circ}\end{array}$ & $\begin{array}{l}0.3 \mathrm{gm} . \\
2 \cdot 3 \mathrm{gm} . \\
8 \cdot 7 \mathrm{gm} .\end{array}$ & $\begin{array}{l}\text { Light blue } \\
\text { Very light blue } \\
\text { Light blue tint }\end{array}$ \\
\hline
\end{tabular}

